\title{
Analysis of the presence of FLT3 gene mutation and association with prognostic factors in adult and pediatric acute leukemia patients
}

\author{
Graciele Burnatt ${ }^{1}$, Marley Aparecida Licínioํㅜ, Pâmela Cristina Gaspar ${ }^{1}$, Arthur Schveitzer \\ Ferreira $^{2}$, Manoela Lira Reis ${ }^{1}$, Ana Carolina Rabello de Moraes ${ }^{1,2}$, Thaís Cristine Marques \\ Sincero ${ }^{1,2}$, Maria Cláudia Santos-Silva ${ }^{1,2^{*}}$
}

${ }^{1}$ Postgraduate Program in Pharmacy, Department of Clinical Analyses, Health Sciences Centre, Federal University of Santa Catarina, Florianópolis, SC, Brazil, ${ }^{2}$ Department of Clinical Analyses, Health Sciences Centre, Federal University of Santa Catarina, Florianópolis, SC, Brazil

\begin{abstract}
When the FLT3 gene is mutated, it originates a modified receptor with structural changes, which give survival advantage and malignant hematopoietic cell proliferation. Thus, the presence of mutations in this gene is considered an unfavorable prognostic factor. A total of 85 consecutive samples of newly diagnosed untreated patients with AL were included in the study after they provided their informed consent. FLT3 gene mutations were detected by PCR. For the pediatric group, a positive correlation was observed between WBC count and the presence of FLT3-ITD in patients with AML and ALL. Furthermore, children with AML who had the FLT3-ITD mutation showed a tendency to express CD34 in blast cells. In the adult group, the AML patients with FLT3-ITD who expressed CD34 in blast cells had a tendency to worse progression. The present data indicate no association between the prognostic factors evaluated and FLT3 gene mutations in adult with AL. Yet, the presence of FLT3-ITD mutation was significantly related with WBC count in the pediatric group. These findings demonstrate that FLT3 gene mutations can be considered as independent poor prognostic factors.
\end{abstract}

Uniterms: FLT3-ITD/mutation. Acute leucemia/prognostic factors. Acute leucemia/adults patients. Acute leucemia/pediatric patients. AML. ALL. FLT3-D835.

\section{INTRODUCTION}

Acute leukemia (AL) is a group of heterogeneous diseases characterized by fast and uncontrolled proliferation of hematopoietic progenitor cells in bone marrow, which eventually reach the peripheral circulation and can infiltrate other organic systems (McCulloch, 1982). In recent years, progress in the understanding of genetics and cellsignaling pathways has provided useful tools to stratify acute leukemia patients into different prognostic subgroups based on cytogenetic and molecular characteristics (Liersch et al., 2014). Prognostic factors in malignant diseases are positively or negatively associated with one or more

\footnotetext{
*Correspondence: M.C. Santos-Silva. Departamento de Análises Clínicas. Centro de Ciências da Saúde. Universidade Federal de Santa Catarina. Campus Trindade - 88040-900 - Florianópolis - SC, Brasil. E-mail: maria.claudia.silva@ufsc.br
}

outcome parameters. Thus, they prove to be useful in deciding upon appropriate therapy (Liersch et al., 2014). According to current diagnostic criteria of the World Health Organization (WHO) (Swerdlow et al., 2008), immunophenotyping, cytogenetics, and molecular genetic characteristics, among other prognostic correlations such as white-blood-cell (WBC) count, patient age, and percentage of blasts are related to prognosis and contribute to the stratification of AL (Swerdlow et al., 2008). The risk stratification into favorable, intermediate, and adverse is based upon cytogenetic risks and molecular genetic alterations such as FLT3, KIT, NPMI, and CEPBPA. Among these, mutations on the gene that transcribes the FMSlike tyrosine kinase 3 (FLT3) receptor are very important because they are found in approximately $30 \%$ of patients with acute myeloblastic leukemia (AML) and correlated with a poor prognosis (Koh et al., 2009). 
The FLT3 gene is located in chromosome $13 \mathrm{q} 12$ and encodes a transmembrane protein that plays a crucial role in normal hematopoiesis (Baldus et al., 2007). The two main types of mutation in this gene are an internal tandem duplication (FLT3-ITD) in exons 14 and 15, and a missense point mutation in codon 835 in exon 20 (FLT3-D835). Both mutations produce a constitutively active tyrosine-kinase receptor, despite the absence of its ligant, leading to disturbance in the normal hematopoiesis (Baldus et al., 2007; Small, 2006; Gale, Green, Allen, 2008).

In this context, the objective of the present study is to evaluate the association between the presence of FLT3 gene mutations in adults and children with AL and other prognostic factors or clinical progression.

\section{PATIENTS AND METHODS}

A total of 85 consecutive samples of bone marrow and/or peripheral blood were collected from patients with AL. The subjects comprised adult patients from University Hospital of Federal University of Santa Catarina, Florianopolis, Brazil, and pediatric patients from Children Hospital Joana de Gusmão of Santa Catarina, Florianopolis, Brazil. The samples were collected and evaluated for the presence of FLT3 mutations in the period of January 2012 to September 2014. All the patients were included in the study after they provided their informed consent.

Due to differences in outcome between children and adults with AL, patients were divided into pediatric and adult groups according to age. Patients below 16 years old were considered as belonging to the pediatric group, while patients 16 years old or more were included in the adult group. A total of 45 patients ( 22 females and 23 males; median age of 41 years, ranging from 16 to 87 years old) were included in the adult group, while 40 children (17 female and 22 male, median age of 4.5 years, ranging from one month to 15 years old) were included in the pediatric group (Table I).

TABLE I - Clinical and laboratory characteristics of patients diagnosed with LA at the time of diagnosis

\begin{tabular}{|c|c|c|c|c|}
\hline \multirow[b]{2}{*}{ Parameters } & \multicolumn{2}{|c|}{ ADULT GROUP } & \multicolumn{2}{|c|}{ PEDIATRIC GROUP } \\
\hline & $\mathrm{N}(45)$ & $\%$ & $\mathrm{~N}(40)$ & $\%$ \\
\hline \multicolumn{5}{|l|}{ Gender } \\
\hline Female & 22 & 35.7 & 17 & 42.5 \\
\hline Male & 23 & 64.3 & 23 & 57.5 \\
\hline \multicolumn{5}{|c|}{ Subtipo de leucemia } \\
\hline AML & 27 & 60.0 & 12 & 30.0 \\
\hline LLA & 18 & 30.0 & 28 & 70.0 \\
\hline \multicolumn{5}{|l|}{$\overline{\text { Age (years) }}$} \\
\hline Mediana & 41.0 & & 4.5 & \\
\hline Interval & $16-87$ & & $0.1-15$ & \\
\hline \multicolumn{5}{|l|}{ CD34 } \\
\hline Positive & 28 & 62.2 & 35 & 87.5 \\
\hline Negative & 17 & 37.8 & 05 & 12.5 \\
\hline \multicolumn{5}{|c|}{$\overline{\mathrm{WBC}\left(\mathrm{x} 10^{3} / \mathrm{mm}^{3}\right)}$} \\
\hline Median & 6.7 & & 24.5 & \\
\hline Interval & $0.4-288.7$ & & $2.0-450.0$ & \\
\hline \multicolumn{5}{|l|}{$\overline{\mathrm{LDH}(\mathrm{U} / \mathrm{L})}$} \\
\hline Median & 327.5 & & 967.0 & \\
\hline Interval & $61-6.500$ & & $322-14.559$ & \\
\hline \multicolumn{5}{|l|}{ Blasts (\%) } \\
\hline Median & 38,0 & & 84,5 & \\
\hline Interval & $0,0-97,0$ & & $21.0-98.0$ & \\
\hline \multicolumn{5}{|c|}{ FLT3 Mutation } \\
\hline Positive & 07 & & 08 & 20.0 \\
\hline Negative & 38 & & 32 & 80.0 \\
\hline
\end{tabular}

WBC - White-blood-cell; LDH - Lactate dehydrogenase; AL - Acute leukemia. 
Diagnosis and subclassification of AL were based on morphological evaluation, immunophenotyping and molecular genetic studies $[\mathrm{t}(15 ; 17), \mathrm{t}(8 ; 21), \mathrm{t}(16 ; 16)$ and $t(9 ; 22)$ ] according to the criteria of the World Health Organization Classification of Tumors of Hematopoietic and Lymphoid Tissue (Swerdlow et al., 2008). Because many patients did not have karyotype request or because patient's samples did not have cell growth, it was not possible to access all karyotypes results from all patients included in this study. Thus, only the results of genetic alterations investigated by molecular biology were considered for AL classification. A total of 39 patients were diagnosed with AML ( 27 adults and 12 children) and 46 patients with acute lymphoblastic leukemia (ALL - 18 adults and 28 children). The distribution was as follows: AML ( 5 cases; $5.9 \%$ ), AML without maturation ( 5 cases; 5.9\%), AML with maturation (6 cases; 7.0\%), AML with $\mathrm{t}(8 ; 21)$ ( 1 case; $1.2 \%)$, acute promyelocytic leukemia with $\mathrm{t}(15 ; 17)$ (14 cases; $16.5 \%)$, acute myelomonocytic leukemia ( 1 case; $1.2 \%$ ), acute monoblastic leukemia ( 5 cases; $5.9 \%$ ), acute monocytic leukemia (1 case; $1.2 \%$ ), acute megakaryoblastic leukemia (1 case; $1.2 \%$ ), B-derived ALL (35 cases; 41.2\%), B-derived ALL with $\mathrm{t}(9 ; 22)$ (2 cases; $2.3 \%$ ) and T-derived ALL ( 9 cases; $10.5 \%)$.

For the analysis of correlation between the presence of FLT3 mutations (ITD or D835) and age or WBC count, the adult and pediatric groups were divided according to prognosis. For the adult group, age above 50 years for AML and over 60 years for ALL were considered poor prognosis. Regarding WBC count, AML and ALL were considered of poor prognosis when counts were greater than $20.0 \times 10^{3} / \mathrm{mm}^{3}$ and $10.0 \times 10^{3} / \mathrm{mm}^{3}$, respectively. For the pediatric group, age above nine years and WBC count greater than $50.0 \times 10^{3} / \mathrm{mm}^{3}$ were included in the poor prognosis group. Moreover, the association between the presence of FLT3 gene mutations and the progression of patients after six months of diagnosis was also evaluated; the patients were divided into four groups: remission, relapse, death in remission, and death without remission.

\section{Genomic DNA extraction}

The peripheral blood was use only in the cases that WBC was above $20.0 \times 10^{3} / \mathrm{mm}^{3}$ and perceptual of blast cells were about $20 \%$ at diagnosis. Due the fact that the method of detecting the FLT3 mutation with polymerase chain reaction (PCR) has a limit of detection of approximately 1 in 100 cells (Murphy et al., 2003), when the peripheral blood samples did not match this criterion, the bone marrow sample was used. DNA from peripheral blood or bone marrow was obtained using the commercial QIAmp DNA kit (QIAGEN, USA). Briefly, $200 \mu \mathrm{L}$ of the sample was mixed with $20 \mu \mathrm{L}$ QIAGEN protease in a 1.5 $\mathrm{mL}$ microtube. Cells were lysed using $200 \mu \mathrm{L}$ of AL buffer in the sample, homogenized for 15 seconds and incubated at $56{ }^{\circ} \mathrm{C}$ for 10 minutes. Absoluted ethanol (96-100\%) was added and again the samples were homogenized for 15 seconds. The obtained solution was transferred to the QIAamp column and centrifuged at 6,000 $\mathrm{x} g$ for 1 minute. The filtrate was discarded and $500 \mu \mathrm{LAW} 1$ wash solution was added and the column was centrifuged at $6,000 \mathrm{x} g$ for 1 minute. The column was washed by adding $500 \mu \mathrm{L}$ of a second wash buffer (AW2) and centrifuged at 20-20,000 $\mathrm{x} g$ for 3 minutes. The purified DNA was eluted from the spin columns with $100 \mu \mathrm{L}$ of buffer AE or $100 \mu \mathrm{L}$ of distilled water. Subsequently, the column was incubated for 5 minutes at room temperature and centrifuged at 6,000 $\mathrm{x} g$ for 1 minute. The obtained DNA was stored at $-20^{\circ} \mathrm{C}$ to be used in the next PCR reaction.

\section{Detection of FLT3-ITD mutation}

The Polymerase Chain Reaction (PCR) technique was employed to detect FLT3-ITD mutation. The primers 5'-GCAATTTAGGTATGAAAGCCAGC-3' and 5'-CTTTCAGCATTTTGACGGCAACC-3' used to amplify exons 14 and 15 of the FLT3 gene were previously described by Meshinchi et al. (2001) (Meshinchi et al., 2006). The PCR products were visualized in $12 \%$ polyacrylamide denaturing gel with ethidium bromide staining under $320 \mathrm{~nm}$ UV light transilluminator. The presence of ITD mutation in the FLT3 gene was determined by visualization of a single band larger than $329 \mathrm{bp}$, wildtype gene fragment (homozygous mutation), or by the visualization of $329 \mathrm{bp}$ wild-type gene fragment and one or more fragments larger than $329 \mathrm{bp}$ (heterozygous mutation) as demonstrated in Figure 1. All PCR reagents were purchased from Invitrogen (Carlsbad, CA, USA).

\section{Detection of FLT3-D835 mutation}

The PCR technique followed by the restriction fragment length polymorphism (RFLP) technique described by Liang et al. (2003) were used to detect the FLT3-D835 mutation (Liang et al., 2003). First, the region of exon 20 of the FLT3 gene was amplified using specific primers (5'-CCGCCAGGAACGTGCTTG-3' and 5'-GCAGCCTCACATTGCCCC-3'). Next, the PCR products underwent enzymatic digestion with the enzyme ECO-RV. The digestion products were visualized in a $12 \%$ polyacrylamide gel with ethidium bromide staining under 


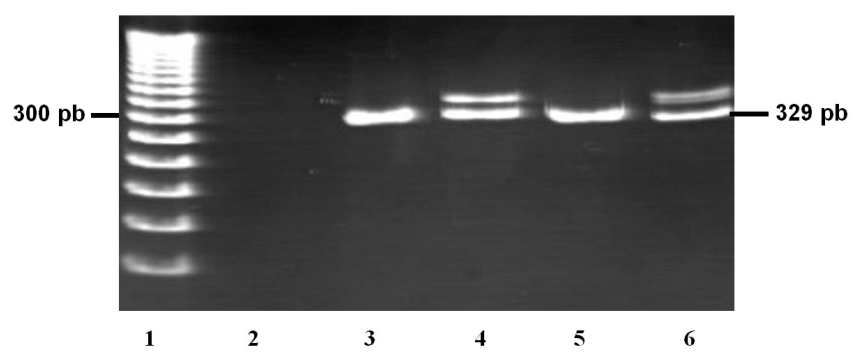

FIGURE 1 - PCR products of FLT3-ITD, analyzed by gel electrophoresis. Reverse view of ethidium-bromide-stained $12 \%$ polyacrylamide gel FLT3-ITD was detected as extra-bands in addition to normal band of $329 \mathrm{bp}$. Line 1- Molecular weight marker (50 bp); Line 2-Water control; Line 3-Patient sample wild type; Line 4- Patient sample with FLT3-ITD mutation; Line 5-wild type control; Line 6-) FLT3-ITD mutation control.

$320 \mathrm{~nm}$ UV light transilluminator. The samples without mutation underwent complete enzymatic digestion, which resulted in the presence of two bands ( $68 \mathrm{bp} / 46 \mathrm{bp}$ ). Heterozygous samples for FLT3-D835 mutation showed three bands (114 bp/68 bp/46 bp) after digestion, while homozygous samples showed a completely undigested band of $114 \mathrm{bp}$ (Figure 2). All PCR reagents were purchased from Invitrogen (Carlsbad, CA, USA).

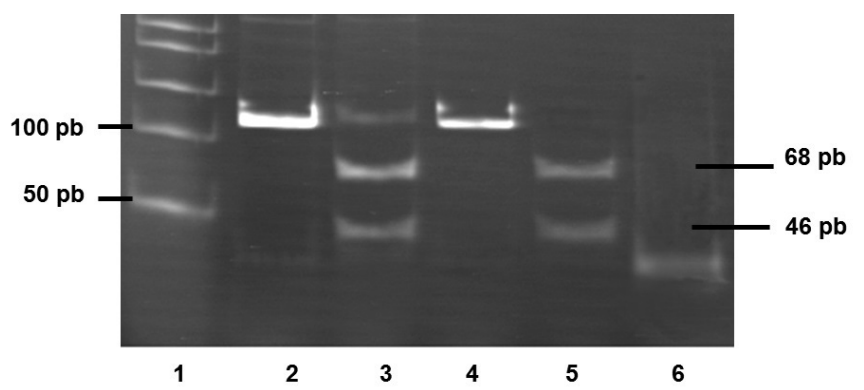

FIGURE 2 - PCR products of FLT3-D835, analyzed by gel electrophoresis. Reverse view of ethidium-bromide-stained $12 \%$ polyacrylamide gel FLT3-D835 was detected as extraband after enzymatic digestion in addition to normal bands of $68 \mathrm{bp}$ and $46 \mathrm{bp}$. Line 1- Molecular weight marker (50 bp); Line 2-PCR product of a patient sample with FLT3-D835 mutation before enzymatic digestion; Line 3-PCR product of a patient sample with FLT3-D835 mutation after enzymatic digestion; Line 4-PCR product of a patient sample with wild type before enzymatic digestion; Line 5-PCR product of a patient sample with wild type after enzymatic digestion; Line 6-Water control.

\section{Statistical analysis}

The association between the presence of FLT3 mutations and nominal variables such as gender, CD34 expression, WBC count at diagnosis, and patient outcome after six months of diagnosis were analyzed using the Chi-square test. Numeric variables such as lactate dehydrogenase activity (LDH) and percentage of blasts were associated with the group of interest using Mann-Whitney U test. A p-value $\leq 0.05$ was considered statistically significant for all analyses. Statistical analyses were done with the software SPSS (version 17.0).

\section{RESULTS}

During the period of this study, 85 samples of bone marrow and/or peripheral blood from patients with $\mathrm{AL}$ were evaluated for the presence of FLT3 mutations.

As displayed in Table II, the FLT3-ITD mutation was observed in three patients in the adult group (6.7\%) and FLT3-D835 mutation in five patients (11.1\%). In the pediatric group, FLT3-IDT mutation was observed in seven patients $(17.5 \%)$ and FLT3-D835 mutation in just one patient $(2.5 \%)$.

According to the subtype in the adult group, it was observed that, of all cases of AML, 7.4\% (two cases) and $14.8 \%$ (four cases) had FLT3-ITD and FLT3-D835, respectively. In adult patients with ALL, $5.6 \%$ (one case) had either FLT3-ITD or FLT3-D835. These results show that there was no correlation between AL subtype and presence of ITD or D835 mutations in adult patients.

The same was observed with the pediatric group, where $33.3 \%$ (four cases) of the patients with AML had the FLT3-ITD mutation, while $10.7 \%$ (three cases) of the patients with ALL showed the same mutation. Although the FLT3-ITD mutation was not associated with the AL subtypes (AML or ALL; $\mathrm{P}=0.168$ ), it was observed that this mutation was more prevalent in children with AML. Mutation FLT3-D835 was detected only in one child (8.3\%) with AML.

Regarding gender, FLT3 mutations were present in $20.8 \%$ (five cases) of males and $13.6 \%$ (three cases) of females in the adult group. In the pediatric group, $17.4 \%$ (four cases) and $23.5 \%$ (four cases) of males and females, respectively, showed FLT3 mutations. No correlation was found between gender and the presence of FLT3 mutations in either group.

As presented in the Table II, there was no correlation between the presence of FLT3-ITD or FLT3-D835 and prognostic factors such as age, WBC count, percentage of blasts, CD34 expression, and LDH activity in the adult group. However, it is important to note that the patients who had FLT3-ITD mutation showed WBC count (median $29.4 \times 10^{3} / \mathrm{mm}^{3}$ ) and LDH activity (median $875.0 \mathrm{U} / \mathrm{L}$ ) above the upper reference values $\left(11.0 \times 10^{3} / \mathrm{mm}^{3}\right.$ and 190.0 $\mathrm{U} / \mathrm{L}$, respectively).

As demonstrated in Table III, for the pediatric group, a 
Analysis of the presence of FLT3 gene mutation and association with prognostic factors in adult and pediatric acute leukemia patients

TABLE II - Values of age, percentage of blasts, WBC count, LDH activity, CD34 expression, and progression of patients with AL according to the absence or presence of FLT3 mutation and group

\begin{tabular}{|c|c|c|c|c|}
\hline \multirow{2}{*}{ ADULT GROUP } & \multicolumn{2}{|c|}{ Presence of $F L T 3$ mutation $(n=7)$} & \multicolumn{2}{|c|}{ Absence of FLT3 mutation $(n=38)$} \\
\hline & Median & Limits & Median & Limits \\
\hline Age (years) & 41.0 & $25.0-73.0$ & 41.0 & $15.0-87.0$ \\
\hline Blasts $(\%)$ & 50.0 & $27.0-96.0$ & 46.0 & $0.0-98.0$ \\
\hline $\mathrm{WBC}\left(\times 10^{3} / \mathrm{mm}^{3}\right)$ & 12.9 & $1.6-288.7$ & 5.9 & $0.4-177.2$ \\
\hline \multirow[t]{2}{*}{$\mathrm{LDH}(\mathrm{U} / \mathrm{L})$} & 875.0 & $259.0-5,189.0$ & 300.0 & $61.0-6,500.0$ \\
\hline & $\mathbf{N}$ & $\%$ & $\mathbf{N}$ & $\%$ \\
\hline CD34 Expression & 4 & 57.2 & 24 & 63.1 \\
\hline Death & 3 & 42.8 & 18 & 47.4 \\
\hline Remission & 4 & 57.2 & 20 & 52.6 \\
\hline \multirow{2}{*}{ PEDIATRIC GROUP } & \multicolumn{2}{|c|}{ Presence of $F L T 3$ mutation $(\mathrm{n}=8)$} & \multicolumn{2}{|c|}{ Absence of $F L T 3$ mutation $(n=32)$} \\
\hline & Median & Limits & Median & Limits \\
\hline Age (years) & 6.5 & $0.10-14.0$ & 4.0 & $0.3-14.0$ \\
\hline Blasts (\%) & 83.0 & $80.0-96.0$ & 83.0 & $21.0-98.0$ \\
\hline $\mathrm{WBC}\left(\mathrm{x} 10^{3} / \mathrm{mm}^{3}\right)$ & 51.3 & $27.5-220.0$ & 14.8 & $2.0-450.0$ \\
\hline \multirow[t]{2}{*}{$\mathrm{LDH}(\mathrm{U} / \mathrm{L})$} & $1,227.0$ & $786.0-13,087.0$ & 955.0 & $322.0-14,559.0$ \\
\hline & $\mathbf{N}$ & $\%$ & $\mathbf{N}$ & $\%$ \\
\hline CD34 Expression & 7 & 87.5 & 28 & 87.5 \\
\hline Death & 5 & 62.5 & 8 & 25.0 \\
\hline Remission & 3 & 37.5 & 24 & 75.0 \\
\hline
\end{tabular}

WBC - White-blood-cell; LDH - Lactate dehydrogenase; AL - Acute leukemia.

positive correlation was observed between WBC count and the presence of FLT3-ITD in patients with AML $(\mathrm{p}=0.007)$ and ALL ( $\mathrm{p}=0.005)$. Furthermore, children with AML who had the FLT3-ITD mutation showed a tendency to express CD34 ( $\mathrm{p}=0.078)$. Similar to the adult group, children who had FLT3-ITD mutation showed LDH activity (median $1,292.0 \mathrm{U} / \mathrm{L}$ ) above the maximum reference value. There was no correlation between FLT3-D835 mutation and the prognostic factors for the pediatric group. The association between the presence of FLT3 gene mutations and the patient progression after six months of diagnosis was also evaluated. In the adult group, the AML patients with FLT3ITD who expressed CD34 tended to worse progression $(p=0.067)$. Regarding the pediatric group, there were no significant correlations between patient progression and presence of FLT3 gene mutations.

\section{DISCUSSION}

Treatment of patients with FLT3 mutation represents a great clinical challenge. Patients with these mutations carry a particularly poor prognosis, with greater relapse rate, and inferior overall survival when compared to patients with AL without this mutation (Taketani et al., 2004; Fedders et al., 2015; Wellmann et al., 2015). Given the poor prognosis of patients with AL and FLT3 mutation, mainly FLT3-ITD, it has become a common practice to do allogeneic bone marrow transplantation during first remission in patients with these mutations. However, there remains a significant relapse rate following transplant for FLT3-ITD, and it is possible that maintenance therapy with FLT-3 inhibitors will reduce the recurrence rates (Taketani et al., 2004; Bornhauser et al., 2007; Schlenk et al., 2008; Dezern et al., 2011; Hassanein et al., 2016). Recently, FLT3 inhibitors have emerged as a new option of treatment for these patients. Several FLT3 inhibitors have been tried as monotherapy or combined with other chemotherapeutic agents (Hassanein et al., 2016).

Nevertheless, it is still unclear how and when these agents should be use during AML treatment (Hassanein et al., 2016). Because of the impact of FLT3 mutation on prognosis and treatment protocols, the guidelines from various major organizations, such as National Comprehensive Cancer Network and European LeukemiaNet, recommend FLT3 mutation analysis on diagnosis. 
TABLE III - Association between prognostic factors and presence of FLT3-IDT and FLT3-D835 mutations in adults with acute leukemia

\begin{tabular}{lcccc}
\hline & \multicolumn{2}{c}{ LMA (n=27) } & \multicolumn{2}{c}{ LLA (n=18) } \\
\cline { 2 - 5 } & $\begin{array}{c}\text { FLT3-ITD } \\
\text { (P values) }\end{array}$ & $\begin{array}{c}\text { FLT3-D835 } \\
\text { (P values) }\end{array}$ & $\begin{array}{c}\text { FLT3-ITD } \\
\text { (P values) }\end{array}$ & $\begin{array}{c}\text { FLT3-D835 } \\
\text { (P values) }\end{array}$ \\
\hline Age $^{\mathrm{a}}$ & 0.430 & 0.608 & 0.167 & 0.500 \\
WBC count at diagnosis $^{\mathrm{a}}$ & 0.156 & 1.000 & 0.444 & 0.444 \\
\% Blasts & 1.000 & 0.612 & 0.111 & 0.667 \\
CD34 expression & 0.091 & 0.609 & 0.111 & 1.000 \\
LDH & 0.271 & 0.157 & 0.556 & 0.222 \\
\hline
\end{tabular}

WBC - White-blood-cell; LDH - Lactate dehydrogenase; a For this analysis the variables age and WBC count at diagnosis were divided into two groups according to prognosis, as follows: Age - poor prognosis is $\geq 50$ years old for AML and $\geq 60$ years old for ALL, good prognosis is $<50$ years old for AML and $<60$ years old for ALL; WBC - poor prognosis is $\geq 20,000 / \mathrm{mm}^{3}$ for AML and $\geq 10,000 / \mathrm{mm}^{3}$ for ALL, good prognosis is $<20,000 / \mathrm{mm}^{3}$ for AML and $<10,000 / \mathrm{mm}^{3}$ for ALL. $* \mathrm{P} \leq 0.05$ is considered to be statistically significant.

TABLE IV - Association between prognostic factors and presence of FLT3-ITD and FLT3-D835 mutations in children with acute leukemia

\begin{tabular}{lcccc}
\hline & \multicolumn{2}{c}{ LMA (n=12) } & \multicolumn{2}{c}{ LLA (n=28) } \\
\cline { 2 - 5 } & $\begin{array}{c}\text { FLT3-ITD } \\
\text { (P values) }\end{array}$ & $\begin{array}{c}\text { FLT3-D835 } \\
\text { (P values) }\end{array}$ & $\begin{array}{c}\text { FLT3-ITD } \\
\text { (P values) }\end{array}$ & $\begin{array}{c}\text { FLT3-D835 } \\
\text { (P values) }\end{array}$ \\
\hline Age $^{\mathrm{a}}$ & 0.295 & 0.417 & 0.904 & - \\
WBC count at diagnosis $^{\mathrm{a}}$ & $0.007^{*}$ & 1.000 & $0.005^{*}$ & - \\
\% Blasts & 0.093 & 0.167 & 0.856 & - \\
CD34 expression & 0.078 & 1.000 & 0.124 & - \\
LDH & 0.111 & 0.667 & 0.514 & - \\
\hline
\end{tabular}

WBC - White-blood-cell; LDH - Lactate dehydrogenase. ${ }^{\text {a }}$ For this analysis, the variables age and WBC count at diagnosis were divided into two groups according to prognosis, as follows: Age - poor prognosis is $\geq 9$ years old, good prognosis is $<9$ years old; WBC: poor prognosis is $>50,000 / \mathrm{mm}^{3}$ for AML and ALL; LDH - lactate dehydrogenase. ${ }^{*} \mathrm{P} \leq 0.05$ is considered to be statistically significant.

Worldwide, the reported incidence of FLT3-ITD in adults with AML is $15-35 \%$ (Nakao et al., 1996; AbuDuhier et al., 2000; Kottaridis et al., 2001; Xu et al., 2005; Amir, Yi-Bin, 2011). Additionally, the FLT3-D835 mutation incidence is $8-12 \%$ in AML cases (Small, 2006). Lucena-Araujo et al. demonstrated that the incidence of FLT3-ITD in Brazilian patients with AML is similar to the other countries, but the FLT3-TKD is lower. This reinforces the idea that there are geographic differences in FLT3 mutation frequency. Considering that Brazil has continental proportions and multiethnic population, it is expected that the incidence of these mutations are different among Brazilian regions. The incidence and clinical relevance of FLT3 mutations in AL patients from Santa Catarina are unknown, and it is important to create regional data to establish public health policies that improve AL with FLT3 mutation treatments in this region (Lucena-Araujo et al., 2010).

The results of this study showed a lower frequency of FLT3-ITD mutation (7.4\%). This discrepancy can be explained by one of the two facts: i) the small number of patients included in the study, or ii) the intrinsic characteristics of the population studied. Furthermore, it should be noted that, as mentioned by Bao et al. (2006), the incidences reported in other studies might be overestimated because the mutation analysis was usually performed on archived samples from patients who usually have leukocytosis, which is generally present in AML carrying FLT3 mutations (Bao et al., 2006). On the other hand, the incidence of the FLT3-ITD mutation in adults with ALL described in other studies $(5-10 \%)$ is similar to that found in the present study (5.6\%) (Kottaridis et 
al., 2001; Amir, Yi-Bin, 2011). However, because only one case was identified in this study, it was difficult to assess properly the relation between this mutation and the prognostic factors.

The incidence of FTL3-ITD in children with AML is lower than in adults (5-16\%) (Gale, Green, Allen, 2008). Regarding this aspect, the results obtained in this study showed higher percentages $(33.3 \%)$. To the best of our knowledge, Al-Tonbary et al. (2009) conducted the only available study on the presence of FLT3-ITD in children with ALL. Unlike the present study, which found an incidence of $10.7 \%$, Al-Tonbary et al. reported that children with ALL did not show the FLT3-ITD mutation. As in the case of the adult group, this difference can be explained by the small number of patients included in this study and by the intrinsic characteristics of the population studied.

In this study, FLT3-D835 incidence rate was $14.8 \%$ in AML cases, which is higher than the rates reported in other works (Small, 2006; Lucena-Araujo et al., 2010). In ALL cases, our results showed FLT3-D835 frequency of $5.6 \%$, with contrast with the literature results, that demonstrated a frequency of 1-3\% (Abu-Duhier et al., 2001; Yamamoto et al., 2001; Thiede et al., 2002).

Concerning the FLT3-D835 mutations in the pediatric group, there was only one case of AML (8.3\%) and no ALL case positive for the mutation. The frequency of this mutation in AML children is in agreement with that mentioned in other pieces of research, which report it as rare (7-10\%) (Meshinchi et al., 2006; Markova et al., 2009). However, the reported incidence of FLT3-D835 in ALL children is $7.5 \%$ (Wang et al., 2010), which is higher than that found in the present study. Based on the incidences described for FLT3-ITD and FLT3-D835 mutations, a variation was observed among studies, which indicates that there are differences in the frequency of these mutations according to geographical areas.

In relation to the distribution of FLT3 mutations according to gender, the present study is consistent with other findings where there is no significant correlation between these two variables (Al-Tonbary et al., 2009; Karabacak et al., 2010).

The prevalence of FLT3 mutations increases with age, but the presence of this mutation seems to have less impact as a prognostic factor in patients above 60 years old than other adverse prognostic factors (Foran, 2010). In this study, no relation was observed between patient age and the presence of FLT3 mutations in either group, which is in agreement with other studies, which also found no association between these variables (Parcell et al., 2006; Wang et al., 2010).
WBC count, LDH activity, and cytogenetic abnormalities at diagnosis are important prognostic factors (Stone, 2009), as are the mutations in the FLT3 gene (Betz, Hess, 2010). The findings related to whether there is a correlation between the mutations in FLT3 gene and WBC count are controversial. While some groups reported an association between these two variables in AML patients (Kottaridis et al., 2001; Thiede et al., 2002; Emerenciano et al., 2008; Peng et al., 2008; Wang et al., 2010), others found no such relationship (Schlenk et al., 2008; Karabacak et al., 2010). According to the classification of genetic abnormalities, mutations in the FLT3 gene are considered class I mutations, which confer a survival advantage and increase cell proliferation (Betz, Hess, 2010). This may explain why so many studies found an association between mutations in the FLT3 gene and WBC count. In the present study, this relationship was not statistically significant in the adult group, but it was observed that the total WBC count was higher for patients who had the FLT3-ITD mutation. In the pediatric group, a significant association was observed between high WBC and presence of FLT3-ITD mutation.

In patients with $A L$, an increase in LDH activity is considered a poor prognostic factor (Varma, Varma, 2008). A study with adult AL patients showed an association between the presence of FLT3 gene mutations and increase in LDH activity (Peng et al., 2008). However, this same observation was not found in another study (Karabacak et al., 2010), as well as in the present one. Nevertheless, in both the adult and the pediatric groups, patients with FLT3 gene mutations showed higher LDH activity $(875.0 \mathrm{U} / \mathrm{L}$ and 1,227.0 U/L, respectively) than the highest reference $\operatorname{limit}(190.0 \mathrm{U} / \mathrm{L})$.

Although the patients with FLT3 gene mutations included in this study had high percentages of blast cells in both groups, as reported by Liu et al. (2007), the presence of FLT3 gene mutations and percentage of blasts were not statistically related.

Another relevant prognostic factor is the CD34 expression in blast cells. A study by Zhu et al. (2013) showed that CD34 expression is an FLT3-ITD-independent predictor of poor prognosis. In contrast, other studies reported an association between FLT3-ITD mutation and the presence of the CD34 marker in AML patients (Barragán et al., 2011; Zhu et al., 2013). In the present study, no correlation between FLT3 gene mutations and CD34 expression were found. However, four of the five positive patients for FLT3-D835 expressed CD34.

Several studies demonstrated that the presence of FLT3-ITD in AML patients might indicate unfavorable disease course including higher death rate and shorter 
disease-free survival clearly associated with leukocytosis. These findings classify FLT3-ITD as a poor-prognostic mutation (Zhu et al., 2013). Mathews et al. (1991) suggest that there is an inverse relationship between the rate of molecular remission and patients with the presence of FLT3-ITD mutation. In the present study, no association was found between the presence of FLT3-ITD mutation and a poor outcome (death or relapse) in adult patients. Nevertheless, the AML pediatric group showed a tendency of association between FLT3-ITD and death, which characterizes it as an indicator of poor prognosis. Studies have not shown a significant relation between FLT3-D835 mutation and complete remission, disease-free survival, or overall survival (Matthews et al., 1991; Wang et al., 2010). These findings are consistent with the results presented in this study.

\section{CONCLUSIONS}

In conclusion, the present analysis showed that there is no association between the evaluated prognostic factors such as age, LDH activity, and CD34 expression and FLT3 gene mutations in adult and pediatric patients with AL. Nevertheless, the presence of FLT3-ITD mutation was significantly related to WBC count in the pediatric group. These results suggest that the FLT3 gene mutations are independent poor prognostic factors.

\section{ACKNOWLEDGEMENTS}

This research was supported by grants and fellowships from the National Counsel of Technological and Scientific Development - CNPq (Brazil), the Coordination for the Improvement of Higher Education Personnel - CAPES (Brazil), and Fundação de Amparo à Pesquisa e Inovação do Estado de Santa Catarina FAPESC. We thank Professor Dr Maria Luiza Bazzo for allowing us the use of her molecular biology laboratory facilities.

\section{REFERENCES}

ABU-DUHIER, F.M.; GOODEVE, A.C.; WILSON, G.A.; GARI, M.A.; PEAKE, I.R.; REES, D.C.; VANDENBERGHE, E.A.; WINSHIP, P.R.; REILLY, J.T. FLT3 internal tandem duplication mutations in adult acute myeloid leukaemia define a highrisk group. Br. J. Haematol., v.111, n.1, p.190$195,2000$.
ABU-DUHIER, F.M.; GOODEVE, A.C.; WILSON, G.A.; CARE, R.S.; PEAKE, I.R.; REILLY, J.T. Identification of novel FLT-3 Asp835 mutations in adult acute myeloid leukaemia. Br. J. Haematol., v.113, n.1, p.983-988, 2001.

AL-TONBARY, Y.; MANSOUR, A.K.; GHAZY, H.; ELGHANNAM, D.M.; ABD-ELGHAFFAR, H.A. Prognostic significance of foetal-like tyrosine kinase 3 mutation in Egyptian children with acute leukaemia. Int. J. Lab. Hematol., v.31, n.3, p.320-326, 2009.

AMIR, F.T; YI-BIN, C. Treatment of FLT3-ITD acute myeloid leukemia. Blood Res., v.1, n.2, p.175-189, 2011.

BALDUS, C.D.; MRÓZEK, K.; MARCUCCI, G.; BLOOMFIELD, C.D. Clinical outcome of de novo acute myeloid leukaemia patients with normal cytogenetics is affected by molecular genetic alterations: a concise review. Br. J. Haematol., v.137, n.1, p.387-400, 2007.

BAO, L.; WANG, X.; RYDER, J.; JI, M.; CHEN, Y.; CHEN, H.; SUN, H.; YANG, Y.; DU, X.; KERZIC, P.; GROSS, S.A.; YAO, L.; LV, L.; FU, H.; LIN, G.; IRONS, R.D. Prospective study of 174 de novo acute myelogenousleukemias according to the WHO classification: Subtypes, cytogenetic features and FLT3 mutations. Eur. J. Haematol., v.77, n.1, p.35-45, 2006.

BARRAGÁN, E.; MONTESINOS, P.; CAMOS, M.; GONZÁLEZ, M.; CALASANZ, M.J.; ROMÁN-GÓMEZ, J.; GÓMEZ-CASARES, M.T.; AYALA, R.; LÓPEZ, J.; FUSTER, Ó.; COLOMER, D.; CHILlÓN, C.; LARRAYOZ, M.J.; SÁNCHEZ-GODOY, P.; GONZÁLEZCAMPOS, J.; MANSO, F.; AMADOR, M.L.; VELLENGA, E.; LOWENBERG, B.; SANZ, M.A. Prognostic value of FLT3 mutations in patients with acute promyelocytic leukemia treated with all-trans retinoic acid and anthracycline monochemotherapy. Haematologica, v.96, n.10, p.1470-1477, 2011.

BETZ, B.L.; HESS, J.L. Acute Myeloid Leukemia Diagnosis in the 21 st Century. Arch. Pathol. Lab. Med., v.134, n.1, p.1427-33, 2010.

BORNHÄUSER, M.; ILLMER, T.; SCHAICH, M.; SOUCEK, S.; EHNINGER, G.; THIEDE, C. Improved outcome after stem-cell transplantation in FLT3/ITD-positive AML. Blood, v.109, n.5, p. 2264-2265, 2007. 
DEZERN, A.E.; SUNG, A.; KIM, S.; SMITH, B.D.; KARP, J.E.; GORE, S.D.; JONES, R.J.; FUCHS, E.; LUZNIK, L.; MCDEVITT, M.; LEVIS, M. Role of allogeneic transplantation for FLT3/ITD acute myeloid leukemia: outcomes from 133 consecutive newly-diagnosed patients from a single institution. Biol. Blood. Marrow Transplant, v.17, n.9, p.1404-1409, 2011.

EMERENCIANO, M.; MENEZES, J.; VASQUEZ, M.L.; ZALCBERG, I.; THULER, L.C.S.; POMBO-DEOLIVEIRA, M.S.; THE BRAZILIAN COLLABORATIVE STUDY GROUP OF INFANT ACUTE LEUKEMIA. Clinical relevance of FLT3 gene abnormalities in Brazilian patients with infant leukemia. Leuk. Lymphoma, v.49, n.12, p.2291-2297, 2008

FEDDERS, H.; SCHEWE, MARTIN, D.; ZIMMERMANN, M.; ALSADEQ, M.; MOERICKE, A.; STADT, U.Z.; HORSTMANN, A.; PIETERS, R.; SCHRAPPE, M.; CARIO, G.; STANULLA, M. Constitutive activation of FLT3 is a positive prognostic factor in infants with MLLrearranged acute lymphoblastic leukemia. Blood, v.126, p. $1417,2015$.

FORAN, J.M. New prognostic markers in acute myeloid leukemia: perspective from the clinic. Hematol. Am. Soc. Hematol. Educ. Program, v.2010, n.1, p.47-55, 2010.

GALE, R.E.; GREEN, C.; ALLEN, C. The impact of FLT3 internal tandem duplication mutant level, number, size, and interaction with NPM1 mutations in a large cohort of young adult patients with acute myeloid leukemia. Blood, v.111, n.5, p.2776-2784, 2008.

HASSANEIN, M.; ALMAHAYNI, M.H.; AHMED S.O.; GABALLA, S.; FAKIH, R. E. FLT3 inhibitors for treating acute myeloid leucemia. Clin. Lymphoma, Myeloma Leuk., v.16, n.10, p.543-549, 2016.

KARABACAK, B.H.; ERBEY, F.; BAYRAM, I.; YILMAZ, S.; ACIPAYAM, C.; KILINC, Y.; TANYEL, A. Fms-like tyrosine kinase 3 mutations in childhood acute leukemias and their association with prognosis. Asian. Pac. J. Cancer Prev. v.11, n.4, p.923-927, 2010.
KOH, Y. ; PARK, J.; AHN, K.S.; KIM, I.; BANG, S.M.; LEE, J.H.; YOON, S.S.; LEE, D.S.; LEE, Y.Y.; PARK, S.; KIM, B.K. Different clinical importance of FLT3 internal tandem duplications in aml according to FAB classification: possible existence of distinct leukemogenesis involving monocyte differentiation pathway. Ann. Hematol., v.88, n.11, p.1089-1097, 2009.

KOTTARIDIS, P.D.; GALE, R.E.; FREW, M.E.; HARRISON, G.; LANGABEER, S.E.; BELTON, A.A.; WALKER, H.; WHEATLEY, K.; BOWEN, D.T.; BURNETT, A.K.; GOLDSTONE, A.H.; LINCH, D.C. The presence of a FLT3 internal tandem duplication in patients with acute myeloid leukemia (AML) adds important prognostic information to cytogenetic risk group and response to the first cycle of chemotherapy: analysis of 854 patients from the United Kingdom Medical Research Council AML 10 and 12 trials. Blood, v.98, n.6, p.1752-1759, 2001.

LIANG, D.C.; SHIH, L.Y.; HUNG, I.J.; YANG, C.P.; CHEN, S.H.; JAING, T.H.; LIU, H.C.; WANG, L.Y.; CHANG, W.H. FLT3-TKD mutation in childhood acute myeloid leucemia. Leukemia, v.17, n.5, p.883-886, 2003.

LIERSCH, R.; MÜLLER-TIDOW, C.; BERDELW. E.; KRUG, U. Prognostic factors for acute myeloid leukaemia in adultsbiological significance and clinical use. Brit. J. Haematol., v.165, n.1, p.17-38, 2014.

LIU, H.; YU, H.; JIA, H.Y.; ZHANG, W.; GUO, C.J. Detection of FLT3 gene mutation in hematologic malignancies and its clinical significance. Zhongguo Shi Yan Xue Ye Xue Za Zhi, v.15, n.4, p.709-713, 2007.

LUCENA-ARAUJO, A.R.; SOUZA, D.L.; MORATO DE OLIVEIRA, F.; BENICIO, M.T.; FIGUEIREDO-PONTES, L.L.; SANTANALEMOS, B.A.; DOS SANTOS, G.A.; JACOMO, R.H.; DINARTESANTOS, A.R.; YAMAMOTO, M.; SILVA-JR, W.A.; DE LOURDES CHAUFFAILLE, M.; REGO, E.M. Results of FLT3 mutation screening and correlations with immunophenotyping in 169 Brazilian patients with acute myeloid leukemia. Ann. Hematol., v.89, n.2, p.225-228, 2010.

MARKOVA, J.; MARKOVA, J.; TRNKOVA, Z; MICHKOVA, P.; MAALOUFOVA, J.; STARY, J.; CETKOVSKY, P.; SCHWARZ, J. Monitoring of minimal residual disease in patients with core binding factor acute myeloid leukemia and the impact of C-KIT, FLT3, and JAK2 mutations on clinical outcome. Leuk. Lymphoma, v.50, n.9, p.1448-1460, 2009. 
MATTHEWS, W.; JORDAN, C.T.; WIEGAND, G.W.; PARDOLL, D.; LEMISCHKA, I.R. A receptor tyrosine kinase specific to hematopoietic stem and progenitor cellenriched populations. Cell, v.65, n.7, p.1143-52, 1991.

MCCULLOCH, E.A. Stem cells in normal and leukemic hemopoiesis (Henry Stratton Lecture). Blood, v.62, n.1, p.1-13, 1982.

MESHINCHI, S.; WOODS, W.G.; STIREWALT, D.L.; SWEETSER, D.A.; BUCKLEY, J.D.; TJOA, T.K.; BERNSTEIN, I.D.; RADICH, J.P. Prevalence and prognostic significance of FLT3 internal tandem duplication in pediatric acute myeloid leukemia. Blood, v.97, n.1, p.8994, 2001.

MESHINCHI, S.; ALONZO, T.A.; STIREWALT, D.L.; ZWAAN, M.; ZIMMERMAN, M.; REINHARDT, D.; KASPERS, G.J.; HEEREMA, N.A.; GERBING, R.; LANGE, B.J.; RADICH, J.P. Clinical implications of FLT3 mutations in pediatric AML. Blood, v.108, n.12, p.36543661, 2006.

MURPHY, K.M.; LEVIS, M.; HAFEZ, M.J.; GEIGER, T.; COOPER, L.C.; SMITH, B.D.; SMALL, D.; BERG, K.D. Detection of FLT3 internal tandem duplication and D835 mutations by a multiplex polymerase chain reaction and capillary electrophoresis assay. J. Molec. Diagn., v.5, n.2, p.96-108, 2003.

NAKAO, M.; YOKOTA, S.; IWAI, T.; KANEKO, H.; HORIIKE, S.; KASHIMA, K.; SONODA, Y.; FUJIMOTO, T.; MISAWA, S. Internal tandem duplication of the flt3 gene found in acute myeloid leukemia. Leukemia, v.10, n.12, p.1911-1918, 1996.

PARCELL, B.W.; IKEDA, A.K.; SIMMS-WALDRIP, T.; MOORE, T.B.; SAKAMOTO, K.M. FMS-like tyrosine kinase 3 in normal hematopoiesis and acute myeloid leukemia. Stem Cells, v.24, n.1, p.1174-1184, 2006.

PENG, H.L.; ZHANG, G.S.; GONG, F.J.; SHEN, J.K.; ZHANG, Y.; XU, Y.X.; ZHENG, W.L.; DAI, C.W.; PEI, M.F.; YANG, J.J. Fms-like tyrosine kinase (FLT) 3 and FLT3 internal tandem duplication in different types of adult leukemia: analysis of 147 patients. Croat. Med. J., v.49, n.1, p.650$659,2008$.
SCHLENK, R.F.; DÖHNER, K.; KRAUTER, J.; FRÖHLING, S.; CORBACIOGLU, A.; BULLINGER, L.; HABDANK, M.; SPÄTH, D.; MORGAN, M.; BENNER, A.; SCHLEGELBERGER, B.; HEIL, G.; GANSER, A.; DÖHNER, H.; GERMAN-AUSTRIAN ACUTE MYELOID LEUKEMIA STUDY GROUP. Mutations and treatment outcome in cytogenetically normal acute myeloid leukemia. N. Engl. J. Med., v.358, p.1909-1918, 2008.

SMALL, D. FLT3 mutations: biology and treatment. ASH Educ. Program, v.2006, n.1, p.178-184, 2006.

STONE, R.M. Prognostic factors in AML in relation to (ab) normal karyotype. Best Pract. Res. Clin. Haematol., v.22, n.1, p.523-528, 2009.

SWERDLOW, S.H.; CAMPO, E.; HARRIS, N.L.; JAFFE, E.S.; PILERI, S.A.; STEIN, H.; THIELE, J.; VARDIMAN, J.W. WHO classification of tumours of haematopoietic and lymphoid tissues. 4.ed. Geneva: WHO Press, 2008. 439p.

TAKETANI, T.; TAKI, T.; SUGITA, K.; FURUICHI, Y.; ISHII, E.; HANADA, R.; TSUCHIDA, M.; SUGITA, K.; IDA, K.; HAYASHI, Y. FLT3 mutations in the activation loop of tyrosine kinase domain are frequently found in infant ALL with MLL rearrangements and pediatric ALL with hyperdiploidy. Blood, v.103, n.3, p.1085-8, 2004.

THIEDE, C.; STEUDEL, C.; MOHR, B.; SCHAICH, M.; SCHÄKEL, U.; PLATZBECKER, U.; WERMKE, M.; BORNHÄUSER, M.; RITTER, M.; NEUBAUER, A.; EHNINGER, G.; ILLMER, T. Analysis of FLT3-activating mutations in 979 patients with acute myelogenous leukemia: association with FAB subtypes and identification of subgroups with poor prognosis. Blood, v.99, n.12, p.432635,2002 .

VARMA, N.; VARMA, S. Proliferative indices, cytogenetics, immunophenotye and other prognostic parameters in myelodysplastic syndromes. Indian J. Pathol. Microbiol., v.51, n.1, p.97-101, 2008.

WANG, L.; XU, W.L.; MENG, H.T.; QIAN, W.B.; MAI, W.Y.; TONG, H.Y.; MAO, L.P.; TONG, Y.; QIAN, J.J.; LOU, Y.J.; CHEN, Z.M.; WANG, Y.G.; JIN, J. FLT3 and NPM1 mutations in Chinese patients with acute myeloid leukemia and normal cytogenetics. J. Zhejiang Univ. Sci. B., v.11, n.10, p.762-770, 2010. 
WANG, W.; WANG, X.Q.; XU, X.P.; LIN, G.W. Prevalence and prognostic significance of FLT3 gene mutations in patients with acute leukaemia: analysis of patients from the Shanghai Leukaemia Cooperative Group. J. Int. Med. Res., v.38, n.2, p.432-442, 2010.

WELLMANN, S.; MODEREGGER, E.; ZELMER, A.; BETTKOBER, M.; STACKELBERG, A.V.; HENZE, G.; SEEGER, K. FLT3 mutations in childhood acute lymphoblastic leukemia at first relapse. Leukemia, v.19, p.467-468, 2005.

XU, F.; TAKI, T.; YANG, H.W.; HANADA, R.; HONGO, T.; OHNISHI; KOBAYASHI M; BESSHO, F.; YANAGISAWA, M.; HAYASHI, Y. Tandem duplication of the FLT3 gene is found in acute lymphoblastic leukaemia as well as acute myeloid leukaemia but not in myelodysplastic syndrome or juvenile chronic myelogenousleukaemia in children. $\mathrm{Br}$. J. Haematol., v.105, n.1, p.155-162, 2005.
YAMAMOTO, Y.; KIYOI, H.; NAKANO, Y.; SUZUKI, R.; KODERA, Y.; MIYAWAKI, S.; ASOU, N.; KURIYAMA, K.; YAGASAKI, F.; SHIMAZAKI, C.; AKIYAMA, H.; SAITO, K.; NISHIMURA, M.; MOTOJI, T.; SHINAGAWA, K.; TAKESHITA, A.; SAITO, H.; UEDA, R.; OHNO, R.; NAOE, T. Activating mutation of D835 within the activation loop of FLT3 in human hematologic malignancies. Blood, v.97, n.8, p.2434-39, 2001.

ZHU, H-H.; LIU, Y-R.; JIANG, H.; LU, J.; QIN, Y-Z.; JIANG, Q.; BAO, L.; RUAN, G-R.; JIANG, B.; HUANG, X. CD34 expression on bone marrow blasts is a novel predictor of poor prognosis independent of FIT3-ITD in acute myeloid leukemia with the NPM1-mutation. Leukemia Res., v.37, n.1, p.624-630, 2013.

Received for publication on $08^{\text {th }}$ June 2016 Accepted for publication on $23^{\text {rd }}$ December 2016 